\title{
Edible Part Nutritional Value And Calcium Content In Five Lai-Durian (D.zibethinus X D. Kutejensis) Fruit Rind From Loa Kulu East Kalimantan
}

\author{
Odit Ferry Kurniadinata ${ }^{*}$, Song Wenpei ${ }^{2}$, Bernatal Saragih ${ }^{1}$, Rusdiansyah ${ }^{1}$ \\ ${ }^{1}$ Faculty of Agriculture, Mulawarman University, Samarinda, East Kalimantan Province, Indonesia. \\ ${ }^{2}$ College of Horticulture and Landscape Architecture, Zhongkai University of Agriculture and Engineering, Guangzhou, China \\ *Corresponding author: odit.ferry@faperta.unmul.ac.id
}

\section{ARTICLE HISTORY \\ Received : 21 June2021 \\ Revised : 25 September 2021 \\ Accepted : 22 October 2021}

\section{KEYWORDS}

Lai-Durian;

Calcium; Fruits;

Tropical rain forest;

Nutrient value;

\begin{abstract}
The large number of Durio species that grow in Kalimantan illustrates that this area is the most important distribution center for durian relatives. Two of the best-known edible durians in East Kalimantan are Durian (Durio zibethinus) and Lai (Durio Kutejensis). Several studies have been conducted to determine the effect of calcium on the quality of fruits. However, very little information was obtained regarding the effect of Ca on the quality of lai-durian fruit. This research was carried out by collecting data and information about Fruit performance and edible part nutritional value three D. zibenthinus x D. kutejensis plants. The five potential superior plants have some similar in rind moisture factor, ash content, water content, total fat, crude protein, and total dissolved solids. However, there is a difference in flesh thickness which indicates that LK4 has the thickest flesh thickness with an average of $9 \mathrm{~mm}$, while LK5 shows the thinnest average flesh thickness of $4 \mathrm{~mm}$. Meanwhile, when viewed from total carbohydrates, LK3 fruit has the highest total carbohydrate content compared to other fruits, which is 37.477 and energy is $180.357 \mathrm{kcal}$. This study indicates that there is a negative correlation between fruit peel size and calcium content. In large Lai-durian fruits such as LK4 fruit there is a lower amount of calcium than other fruits.
\end{abstract}

This is an open-access article under the CC-BY-SA license.

\section{INTRODUCTION}

Several studies have been conducted to determine the effect of calcium (Ca) on the quality of fruits. However, very little information was obtained regarding the effect of $\mathrm{Ca}$ on the quality of durian fruit. One of the important indicators of nutrient calcium deficiency is the occurrence of cracking in fruits, especially in fruit from plants experiencing drought stress and then a sudden increase in the amount of water that causes an increase in water uptake more quickly into the fruit tissue.

The problem of fruit cracking due to Ca deficiency is almost never found in durian fruit. Durian is one of the main fruits in Indonesia, especially in East Kalimantan. One of the rich diversities that exists is the presence of various types of tropical fruits, most of which are endemic to East Kalimantan (Kurniadinata et al. 2019; Kurniadinata et al. 2020). Indonesia is one of the eight centres of plant genetic diversity in the world, especially for tropical fruits such as durian (Bioversity International 2007; Brown 1997). At present it is recorded that of around 27 species of Durio worldwide, 18 of them are grown in Kalimantan, 11 are in

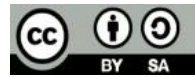

Malaya, and 7 are in Sumatra (Milow et al. 2014). The high number of Durio species that grow in Kalimantan illustrates that this area is the most important distribution centre for durian relatives. In addition to being rich in Durian diversity, Indonesia is also rich in the diversity of sources of germplasm from Durio. For example, durian that is commonly consumed besides Durio zibethinus, namely Lai (Durio Kutejensis), as well as the results of a natural cross between the two. In Indonesia, there are quite a lot of durian cultivars which differ from one another in taste, aroma, and color of the flesh. Even durian seeds can be found without seeds (Rusdiansyah et al. 2020).

Several other studies showed that calcium application can reduce the incidence of fruit cracking, in apples (Knee and Srivastava 1995; Holb et al. 2012), strawberries (Lara et al. 2004), mango (Joyce et al. 2001), peach (Manganaris et al. 2004). al. 2007), kiwi (Montanaro et al. 2006) and tomatoes (Gisslen et al. 1996; Bastias et al. 2010). Calcium becomes the adhesive substance in the cell wall structure in the form of Ca-pectate which binds the pectin chain (Marschner 1995; Huang et al. 2005). 
Although there was no problem of fruit breaking in durian fruit, it is important to know the calcium content in the durian rind. The results of the research by Wenpei et.al. (2018) showed that there was a correlation between fruit growth and Ca uptake and content, especially in fruit rind tissue. Therefore, a study was conducted on the Ca content in the rinds of five fruit plants from crossing durian and Lai in East Kalimantan with a humid topical climate, as well as observations on fruit performance and edible part nutritional value on the fruit of the five Lai-Durian species. This study aims to find out the edible part nutritional value and the calcium content in the fruit peel and the factors that influence it.

\section{MATERIALS AND METHODS}

This research was conducted by using descriptive method of exploration and in laboratory observations. Observations were carried out on fruits from five local laidurian from Loa Kulu, East Kalimantan. The experiment was conducted in Loa Kulu, Kutai Kertanegara, East Kalimantan, Indonesia. All fruits perform, nutritional value and calcium was observed in Agronomy Laboratory, The Faculty of Agriculture, Mulawarman University, Samarinda, East Kalimantan Province, Indonesia, from June to October 2021.

\section{RESULTS AND DISCUSSIONS}

It was reported that in Kalimantan there were 22 species of durian. In general, a cross between $D$. Zhibenthinus and D. Kutejensis in East Kalimantan is referred to as the Lai-Durian plant. However, the characters that appear vary, in plants of the cross D. Zhibenthinus and D. Kutejensis tend to be grouped in the Lai plant given some special features that appear like the color of flowers, fruit and aroma of fruit. Lai Durian has a leaf that are quite large, larger than the leaves of durian but smaller than the Lai leaves, as well as the size of the flowers. The flower is pink, while the durian flowers are white and red. The fruit is gently scented with a sweet flavor and dry texture. The shape of the durian fruit is varied, but generally relatively oval with the color of the flesh varies from yellow to orange. As it is Lai, the fruit Lai durian need to be cured for 4-5 days before maturity, o that the shelf life of fruit after the harvest becomes longer is about 7-10 days.

Calcium is one of the macro nutrients needed by plants and is absorbed in the form of $\mathrm{Ca}^{2+}$. Calcium is immobilized in plant tissues, as is Sulfur (S), Iron (Fe), Boron (B) and Cooper (Cu) (Ignatief and Page 1968; Donahue et al. 1977). The absorption of calcium by plant roots is mainly through mass flow. Calcium is absorbed through young root tissue or root hairs (Himelrick and McDuffie 1983). According to White (2001) and Gilliham et al. (2011) there are two mechanisms of calcium uptake in plant roots, namely:

a. Calcium translocation via apoplast mechanism; calcium is translocated through the intercellular spaces and cell walls

b. Calcium translocation through the symplast mechanism; calcium is translocated between cells, through the cytoplasm of cells.
Mentioned by Tomala et al. (1989) that calcium absorption into fruit tissue occurs continuously and fluctuates in the process of fruit development. Another statement comes from Faust (1989), Wilkinson and Perring (1961), Ford and Quinlan (1979), Fuhr and Wieneke (1974), Hu et al. (1996), Pechkeo et al. (2007) and Wilsdorf (2011) which stated that in general the absorption of calcium by fruit occurs during the early stages of fruit growth and development. Absorption of calcium and boron rapidly by plants mainly occurs early in fruit growth and development, which is translocated through the xylem to the fruit.

The results of the study successfully identified nutritional values and calcium content in five Lai-durian fruits rind in Loa Kulu, Kutai Kertanegara, East Kalimantan Province. In general, the five types of lai-durian in Loa Kulu, not too different in rind moisture factor, which ranges from $15-17 \%$ with an average ash content of $0.5 \%$ in rind. The same applies to water content, total fat, crude protein, and total dissolved solids. However, there is a difference in flesh thickness which indicates that LK4 has the thickest flesh thickness with an average of $9 \mathrm{~mm}$, while LK5 shows the thinnest average flesh thickness of $4 \mathrm{~mm}$. Meanwhile, when viewed from total carbohydrates, LK3 fruit has the highest total carbohydrate content compared to other fruits, which is 37.477 and energy is $180.357 \mathrm{kcal}$. The complete nutritional values content can be seen in Table 1 .

Table 1. Nutritional values of five lai-durian fruits in Loa Kulu

\begin{tabular}{|c|c|c|c|c|c|}
\hline Types of Local Durian & LK1 & LK2 & LK3 & LK4 & LK5 \\
\hline $\begin{array}{l}\text { Rind moisture content } \\
(\%)\end{array}$ & 15,198 & 15,840 & 16,417 & 16,672 & 15,890 \\
\hline Rind ash content (\%) & 0,565 & 0,548 & 0,579 & 0,588 & 0,554 \\
\hline $\begin{array}{l}\text { Flesh Thickness }(\mathrm{mm}) \\
\text { middle }\end{array}$ & 6 & 5 & 8 & 9 & 4 \\
\hline Water content & 59,570 & 59,380 & 55,660 & 56,530 & 56,330 \\
\hline Ash content & 1,649 & 1,635 & 1,658 & 1,649 & 1,641 \\
\hline Total fat & 1,954 & 1,919 & 1,929 & 1,937 & 1,929 \\
\hline Crude protein & 3,284 & 3,293 & 3,272 & 3,331 & 3,321 \\
\hline Total carbohydrates & 33,540 & 33,767 & 37,477 & 36,568 & 36,772 \\
\hline $\begin{array}{l}\text { Total dissolved solids } \\
\left({ }^{\circ} \text { Brix) }\right.\end{array}$ & 11 & 11,5 & 11 & 11 & 11,5 \\
\hline Energy (kcal) & 164,882 & 165,511 & 180,357 & 177,029 & 177,733 \\
\hline
\end{tabular}

The five lai-durians observed had different fruit sizes and shapes. The highest average fruit weight was found in Laidurian LK1. Lai-Durian LK4 had the largest fruit size compared to other Lai-Durian fruits, followed by Lai-Durian LK5, while the smallest fruit size was found in LK2. Fruit size both transverse and longitudinal has a positive correlation with fruit weight, in general it can be said that the larger the size of the lai-durian fruit, the heavier the fruit (Fig. 1).

Table 2. The performance of five local Lai-Durian fruits

\begin{tabular}{lccccc}
\hline $\begin{array}{l}\text { Types of Local } \\
\text { Durian }\end{array}$ & LK1 & LK2 & LK3 & LK4 & LK5 \\
\hline Fruits weight (g) & 940 & 600 & 1100 & 1690 & 1540
\end{tabular}




\begin{tabular}{|c|c|c|c|c|}
\hline Seed Weight (g) & 91.19 & 39.1 & 26.99 & 82.16 \\
\hline Rind Weight (g) & 710 & 440 & 890 & 1095 \\
\hline $\begin{array}{l}\text { Rind Weight } \\
\text { Percent }\end{array}$ & $75.53 \%$ & $73.33 \%$ & $80.91 \%$ & $64.79 \%$ \\
\hline Highest Thorn & 15 & 12 & 14 & 19 \\
\hline \multicolumn{5}{|l|}{ Height (mm) } \\
\hline $\begin{array}{l}\text { Rind Thickness } \\
\text { (mm) middle }\end{array}$ & 8 & 9 & 15 & 10 \\
\hline $\begin{array}{l}\text { Fruit Horizontal } \\
\text { Circumference } \\
(\mathrm{cm})\end{array}$ & 44.5 & 34.5 & 46.3 & 51 \\
\hline $\begin{array}{l}\text { Fruit vertical } \\
\text { Circumference } \\
(\mathrm{cm})\end{array}$ & 50.7 & 47.2 & 57 & 60 \\
\hline $\begin{array}{l}\text { Perimeter } \\
\text { difference } \\
\text { vertical/horizontal } \\
(\mathrm{cm})\end{array}$ & -6.2 & -12.7 & -10.7 & -9 \\
\hline Fruits weight (g) & 940 & 600 & 1100 & 1690 \\
\hline
\end{tabular}

Note: LK=Loa Kulu

Several studies have shown that fruit size affects the calcium content of the fruit and will directly affect the calcium content of the fruit. There is a tendency for calcium deficiency to occur in fruit rind tissue with a larger size compared to a smaller size (De Freitas., 2021). In tomato plants, differences in size affect the calcium content in fruit, where large fruits are more susceptible to calcium deficiency (Indeche et al., 2020).

However, until now there has never find a case of fruit cracking in durian fruit due to calcium deficiency in the rind tissue of the durian fruit. Likewise, various other physiological diseases are generally caused by a lack of calcium. The results of this study indicate that there is a negative correlation between fruit peel size and calcium content. In large lai-durian fruits such as LK4 fruit there is a lower amount of calcium than other fruits (Fig. 2).

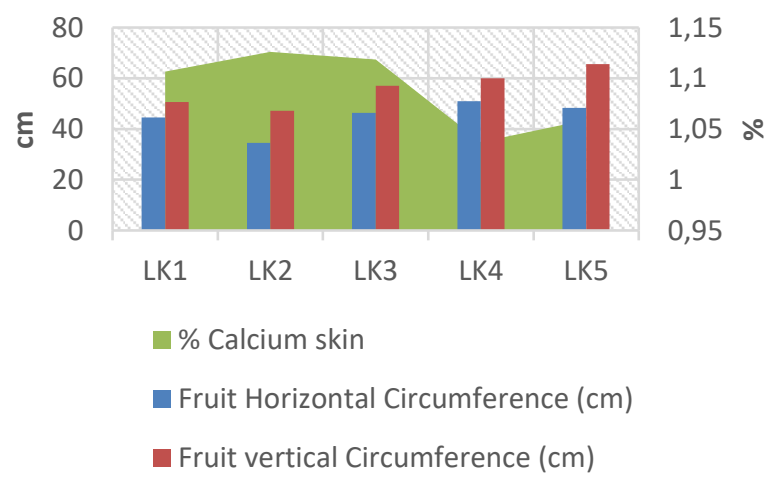

Figure 2. Correlation between \% calcium in durian rind to the fruit's vertical circumference and fruits horizontal circumference

Lai-durian is included in the simple fruit with tube type fruit. In common durian fruit development takes about 95130 days after pollination. Fruit ripening usually heralds the end of the dry season and the on-set of the rainy season. The durian fruit is an indehiscent multilocular capsule which is composed of several fused carpels. The durian may have three to seven carpels. However, the common durian fruit usually has five carpels. Carpels are the
60.56 innermost parts of a complete flower, and they are united to 940 form the gynoecium (pistil). The durian capsule is 61.04\% ripe to disperse its contents. The fruit drops naturally to the 16 ground when ripe. This shows that naturally the five durians used as samples in this study did not break even though they showed different levels of calcium content.

Figure 1 showed that although the durian fruit did not 48.4 find any cracking disease, which is fruit cracking as an indicator of calcium deficiency in the pericarp tissue of the fruit, the rind tissue analysis showed that there was a tendency for large fruits to be susceptible to calcium deficiency. Therefore, it is important to conduct further research on the effect of calcium deficiency and its correlation to fruit size in lai-durian plants. This is because there is no information on the value of calcium content that can cause lai-durian susceptibility to disease and reduce fruit quality. So that in the future it can be known the critical period of calcium needs during fruit development which can then be a reference for recommendations for when calcium fertilization is carried out. As the results of research by Kurniadinata et al. (2016) that there are differences in the amount of calcium translocation at each fruit growth stage.

\section{CONCLUSION}

The five potential superior plants have some similar in rind moisture factor, ash content, water content, total fat, crude protein, and total dissolved solids. However, there is a difference in flesh thickness which indicates that LK4 has the thickest flesh thickness with an average of $9 \mathrm{~mm}$, while LK5 shows the thinnest average flesh thickness of $4 \mathrm{~mm}$. Meanwhile, when viewed from total carbohydrates, LK3 fruit has the highest total carbohydrate content compared to other fruits, which is 37.477 and energy is $180.357 \mathrm{kcal}$. However, this study indicates that there is a negative correlation between fruit peel size and calcium content. In large lai-durian fruits such as LK4 fruit there is a lower amount of calcium than other fruits.

\section{REFERENCES}

Bastías, E., Alcaraz-López, C., Bonilla, I., Martínez-Ballesta, M. C., Bolaños, L., \& Carvajal, M. (2010). Interactions between salinity and boron toxicity in tomato plants involve apoplastic calcium. Journal of Plant Physiology, 167(1), 54-60.

Biodiversity International. 2007. Descriptors For Durian (Durio zibethinus Murr.). Bioversity International. Rome.

Brown, M. J. (1997). Durio, a bibliographic review. Bioversity International. Plant Genetic Resources Institute. India.

de Freitas, S. T., \& Mitcham, E. I. (2012). 3 factors involved in fruit calcium deficiency disorders. Horticultural reviews, 40(1), 107-146.

Donahue, R. L., Miller, R. W., \& Shickluna, J. C. (1983). Soils. An introduction to soils and plant growth. Prentice-Hall, Inc.

Faust, M. (1989). Physiology of temperate zone fruit trees. John Wiley \& Sons, Inc.

Ford, E. M., \& Quinlan, J. D. (1979). The distribution of 45 Ca in apple fruits when supplied to the roots at three times during the season. Journal of Horticultural Science, 54(3), 181-188.

Fuhr, F., \& Wieneke, J. (1974). Secondary translocation of 45Ca to the fruit of apple trees the year after dormancy. Bull R Soc NZ.

Gilliham, M., Dayod, M., Hocking, B. J., Xu, B., Conn, S. J., Kaiser, B. N., Roger, A.L \& Tyerman, S. D. (2011). Calcium delivery and storage in plant leaves: exploring the link with water flow. Journal of experimental botany, 62(7), 2233-2250. 
Gisslen, J. L., Tong, C. B., \& Rosen, C. J. (1996). Effect of EDTA and low calcium fertility on pericarp cation levels and ripening of rin tomato fruit. Postharvest Biology and Technology, 8(4), 279-284.

Himelrick, D. G., DG, H., \& RF, M. (1983). The calcium cycle: uptake and distribution in apple trees.

Holb, I. J., Balla, B., Vámos, A., \& Gáll, J. M. (2012). Influence of preharvest calcium applications, fruit injury, and storage atmospheres on postharvest brown rot of apple. Postharvest Biology and Technology, 67, 29-36.

Hu, H., Brown, P. H., \& Labavitch, J. M. (1996). Species variability in boron requirement is correlated with cell wall pectin. Journal of Experimental Botany, 47(2), 227-232.

Huang, X., Wang, H. C., Li, J., Yin, J., Yuan, W., Lu, J., \& Huang, H. B. (2003, August). An overview of calcium's role in lychee fruit cracking. In II International Symposium on Lychee, Longan, Rambutan and other Sapindaceae Plants 665 (pp. 231-240).

Indeche, A. K., Yoshida, Y., Goto, T., Yasuba, K. I., \& Tanaka, Y. (2020). Effect of defoliation on blossom-end rot incidence and calcium transport into fruit of tomato cultivars under moderate water stress. The Horticulture Journal, 89(1),22-29.

Joyce, D. C., Shorter, A. J., \& Hockings, P. D. (2001). Mango fruit calcium levels and the effect of postharvest calcium infiltration at different maturities. Scientia Horticulturae, 91(1-2), 81-99.

Knee, M., \& Srivastava, P. (1995). Binding of calcium by cell walls and estimation of calcium in apple fruit tissue with an ion selective electrode. Postharvest Biology and Technology, 5(1-2), 19-27.

Kurniadinata, O. F., Wenpei, S., Zaini, A., \& Rusdiansyah, R. (2019). Six Potential Superior Durian Plants Resulted by Cross Breeding of D. zibethinus and D. Kutejensis From East Kalimantan, Indonesia: Initial Identification. Journal of Tropical Horticulture, 2(2), 45-49.

Kurniadinata, O. F., Wenpei, S., \& Rusdiansyah, R. (2020). Morphological Characteristics of Batuah Red-Fleshed Durian (Durio graveolens), an Endemic Exotic Plant from East Kalimantan, Indonesia. Journal of Tropical Horticulture, 3(1), 12-18.

Kurniadinata, O., Depari, S., Poerwanto, R., Efendi, D., \& Wachjar, A. (2016). Solving yellow sap contamination problem in mangosteen (Garcinia mangostana) with $\mathrm{Ca} 2+$ application based on fruit growth stage. Communications in Biometry and Crop Science (2016) 11 (2), 105113.

Lara, I., Garcia, P., \& Vendrell, M. (2004). Modifications in cell wall composition after cold storage of calcium-treated strawberry (Fragariax ananassa Duch.) fruit. Postharvest Biology and Technology, 34(3), 331-339.
Manganaris, G. A., Vasilakakis, M., Diamantidis, G., \& Mignani, I. J. F. C. (2007). The effect of postharvest calcium application on tissue calcium concentration, quality attributes, incidence of flesh browning and cell wall physicochemical aspects of peach fruits. Food chemistry, 100(4), 1385-1392.

Milow, P., Malek, S. B., Edo, J., \& Ong, H. C. (2014). Malaysian species of plants with edible fruits or seeds and their valuation. International Journal of Fruit Science, 14(1), 1-27.

Montanaro, G., Dichio, B., Xiloyannis, C., \& Celano, G. (2006). Light influences transpiration and calcium accumulation in fruit of kiwifruit plants (Actinidia deliciosa var. deliciosa). Plant Science, 170(3), 520-527.

Pechkeo, S., Sdoodee, S., \& Nilnond, C. (2007). The effects of calcium and boron sprays on the incidence of translucent flesh disorder and gamboge disorder in mangosteen (Garcinia mangostana L.). Agriculture and Natural Resources, 41(4), 621-632.

Saragih, B., Zaini, A., \& Kurniadinata, O. F. (2020). Identification of dominan maternal and paternal line characters influence to new find sahang durian plant morphological characters as nature cross-pollination result. EurAsian Journal of Biosciences, 14(2).

Song, W., Yi, J., Kurniadinata, O. F., Wang, H., \& Huang, X. (2018). Linking fruit Ca uptake capacity to fruit growth and pedicel anatomy, a crossspecies study. Frontiers in plant science, 9, 575.

Tomala, K., Araucz, M., \& Zaczek, B. (1989). Growth dynamics and calcium content in McIntosh and Spartan apples. Communications in soil science and plant analysis, 20(5-6), 529-537.

V. Ignatieff \& H.J Page. Efficient Use of Fertilizers. Food \& Agricultural Organization of the United Nations, Viale delle Terme di Caracalla, Rome, Italy.

White, P. J. (2001). The pathways of calcium movement to the xylem. Journal of Experimental Botany, 52(358), 891-899.

Wilkinson, B. G., \& Perring, M. A. (1961). Variation in mineral composition of Cox's Orange Pippin apples. Journal of the Science of Food and Agriculture, 12, 74-80.

Wilsdorf, R. E. (2011). Evaluating the seasonal changes in calcium concentration and distribution in apple fruit after application of different calcium fertilisation strategies (Doctoral dissertation, Stellenbosch: Stellenbosch University) 